\title{
ERÄIDEN TURVELAJIEMME KEMIALLISESTA KOKOOMUKSESTA JA SEN VAIKUTUKSESTA NIIDEN POLTTOARVOON.
}

\author{
U. SOVERI. \\ Geologinen tutkimuslaitos, Helsinki.
}

Saapunut 9.31948

Turpeitten kemiallinen kokoomus kiinnostaa maataloutta etenkin suoviljelysten kannalta sekä teollisuutta polttoturpeen saannin ja muiden turpeenjalostuksen avaamien lukuisten mahdollisuuksien takia. Sen vuoksi onkin turvekemiallinen tutkimus paisunut laajaksi yhdessä mikrobiologisen, fysiikallisen ja geologisen turvetutkimuksen kanssa. On todettu, että samojen turpeitten ja turpeita muodostavien kasvien kemiallinen kokoomus vaihtelee huomattavasti m.m. ilmastollisten ja geologisten y.m. alueellisten tekijöitten vaikutuksesta. Siksi on syytä kiinnittää entistä enemmän huomiota myös suorikkaan Suomen turpeitten kemiaan, silmälläpitäen laajentunutta ja monipuolista soiden ja turpeitten hyväksikäyttöä.

Turpeitten kemialliset rakennusaineet ovat peräisin turvetta muodostavista kasveista, niitä hajoittavista maassa elävistä pieneliöistä sekä veden ja tuulen tuomista lisäaineksista. Mitä moninaisimman pieneliötoiminnan ja kemiallisten prosessien vuoksi turpeitten kokoomus muuttuu niiden maatumisen edistyessä. Tämän tutkimuksen tarkoituksena on antaa kuva muutamien meikäläisten turvelajien päärakennusaineryhmien laadusta, esiintymisestä ja merkityksestä polttoturpeessa. Sitä varten on ensi sijassa tarpeen kokonaisanalyysi, josta käy selville turpeitten energeettisesti tärkeimmät rakenneosat, kuten bitumiaineet, veteen liukenevat orgaaniset aineet, hapoilla hydrolysoituvat aineet, typpiyhdisteet, hapoilla hydrolysoitumattomat aineet sekä tuhka.

\section{Metodiikka.}

Turpeen analysoimiseksi ovat m.m. Oden ja Lindberg (15), Thiessen ja Johnsson (21), Christiansson (2), Waksman ja Stewens $(23,24)$ y.m. esittäneet menetelmiä. Tähän tutkimukseen otetut turvenäytteet n:o $1-18$ on analysoitu käyttämällä WAKSMANin ja STEWENsin esittämää analyysimenetelmää, joka tätä tutkimusta varten lyhennettynä on seuraava: 
1. Eetteriu tos:

N. 5 g. ilmakuivaa turvetta uutetaan 16-24 t. soksletissa eetterillä. Ekstrakti haihdutetaan, kuivataan $100^{\circ}$ :ssa ja punnitaan.

2. Vesiu tos:

Jäännöstä käsitellään $150 \mathrm{ccm}: n$ kanssa vettä huoneenlämpötilassa $24 \mathrm{t}$. ja sitten vesihauteella $3 \mathrm{t}$., minkä jälkeen suodatetaan ja osasta suodosta määritetään siihen liuenneet aineet haihduttamalla se kuiviin, ja uutteen tuhka hehkuttamalla jäännöstä. Toisesta osasta määritetään typpi.

3. Alkoholiuutos:

Jäännös käsitellään $150 \mathrm{ccm}: 11$ ä alkoholia vesihauteella ja määritetään alkoholiin liukeneva osa haihduttamalla suodatettu uute kuiviin. Jäännös punnitaan.

4. Käsittely miedolla suolah a polla:

Alkoholiuutoksen jälkeen keitetään materiaalia 5 t. $2 \%: n \mathrm{HCl}$ :n kanssa käyttäen pystyjäähdyttäjää, suodatetaan, pestään, kuivataan ja punnitaan. Liuoksesta määritetään typpi Kjelldahl-Jodblauerin mukaan sekä hemiselluloosa kertomalla Bertrandin mukaan saatu sokeri 0,9:1lä.

5. Käsittely väkevällä rikkihapolla:

Selluloosa määritetään kahdesta 1 g:n suuruisesta määrästä jäännöstä käsittelemällä niitä erikseen $10 \mathrm{ccm}: 11 \mathrm{a} \quad 80 \% \quad \mathrm{H}_{2} \mathrm{SO}_{4}$ huoneen lämpötilassa $2 \frac{1}{2}$ tuntia, minkä jälkeen lisätään $140 \mathrm{ccm}$ vettä ja keitetään pystyjäähdyttäjää käyttäen 5 t. Liuos suodatetaan ja jäännökset pestään, kuivataan ja punnitaan. Suodoksesta määritetään selluloosa ja typpi kuten edellä. Jäännöksestä määritetään tuhka ja

typpi. Kertomalla happofraktioitten typpimäärät 6,25:1lä saadaan vastaava raakaproteiini.

Näytteet 19-26 on analysoitu lyhyemmällä menetelmällä siten, että eetteri- ja alkoholiuutoksen sijasta on ensin suoritettu bitumimääritys soksletissa bentsolin ja alkoholin seoksella (1: 1). Tämän jälkeen on jäännöksestä tehty vesiuute sekä käsitelty suolahapolla ja rikkihapolla kuten yllä. Tuhka on määritetty vain veteen liukenevasta osasta ja lopullisesta jäännöksestä (Typpi- ja sokerimääritykset jätettiin tässä yhteydessa tekemättä).

Ligniini y.m. hydrolysoitumattomat aineet on eristetty kalorimetriarvon määritystä varten tekemällä ensin bitumimääritys bentsolin ja alkoholin seoksella. Jäännöstä on sen jälkeen käsitelty kuten yllämainitussa Waksmanin menetelmässä $80 \% \quad \mathrm{H}_{2} \mathrm{SO}_{4}: 11$ ä. Kuivatusta jäännöksestä on tehty tuhkaja kalorimetriarvojen määritykset.

Kalorimetriset polttoarvomääritykset on tehty $300 \mathrm{ml}$ pommissa käyttämällä 20 atm:n painetta ja 1-1,2 g:n puristettuja turvekapseleita. Tulokset on laskettu kuivalle, tuhkattomalle aineelle.

Laboratoriotyöt on suoritettu Geologisen tutkimuslaitoksen maalajilaboratoriossa Helsingissä ja siellä on tekijää avustanut m.m. ylioppilas E. KARPPINEN ja farmaseutti Hedvig Cajander.

\section{Tutkimuksessa käytetty turvemateriaali.}

Tutkimuksessa on käytetty Geologisen Tutkimuslaitoksen polttoturvesoitten inventoinnin yhteydessä kerättyjä turvenäytteitä. Näytteet $15-18$ on ystävällisesti käyttööni luovuttanut prof. E. Kivinen. Geologisen tutkimuslaitoksen näytteitten turvelajit on kenttämääritysten tueksi mikroskooppisesti määrännyt fil.maist. E. UUsSAARI ja sekä turvelajit että maatumisasteet tarkistanut fil. tri M. SALMi. 


\begin{tabular}{|c|c|}
\hline Turvekaava (v. Post) & Ottopaikka \\
\hline 1. $\mathrm{S}-\mathrm{t} \mathrm{H}_{2} \mathrm{~B}_{3} \mathrm{~F}_{0} \mathrm{R}_{0} \mathrm{~V}_{0}$ & Matoneva, Töysä \\
\hline 2. $\mathrm{ErS}-\mathrm{t} \mathrm{H}_{2} \mathrm{~B}_{3} \mathrm{~F}_{0-1} \mathrm{R}_{0-1} \mathrm{~V}_{0}$ & Keltamäenneva, Nurmo \\
\hline 3. $\mathrm{S}-\mathrm{t} \mathrm{H}_{5} \mathrm{~B}_{3} \mathrm{~F}_{0} \mathrm{R}_{0} \mathrm{~V}_{0}$ & Ruohoneva, Parkano \\
\hline 4. $\mathrm{S}-\mathrm{t} \mathrm{H}_{7} \mathrm{~B}_{3} \mathrm{~F}_{0} \mathrm{R}_{0} \mathrm{~V}_{0}$ & Viherperän neva, Kankaanpää \\
\hline 5. $\mathrm{S}-\mathrm{t} \mathrm{H}_{5} \mathrm{~B}_{3} \mathrm{~F}_{0} \mathrm{R}_{0-1} \mathrm{~V}_{0}$ & " \\
\hline 6. $\mathrm{S}-\mathrm{t} \mathrm{H}_{6} \mathrm{~B}_{3} \mathrm{~F}_{0-1} \mathrm{R}_{0-1} \mathrm{~V}_{0}$ & Verkkoneva, Pihlajavesi \\
\hline 7. $\mathrm{S}-\mathrm{t} \mathrm{H}_{9} \mathrm{~B}_{3} \mathrm{~F}_{0} \mathrm{R}_{0} \mathrm{~V}_{0}$ & Ylälauttalammen neva, Ikaalinen \\
\hline 8. resist. Carex rostrata & Kälviä \\
\hline 9. $\mathrm{C}-\mathrm{t} \mathrm{H}_{4}$ & Munasuo, Pyhtää \\
\hline 10. $\mathrm{LC}-\mathrm{t} \mathrm{H}_{5}$ & Honkisaari, Säräisniemi \\
\hline 11. $\mathrm{LC}-\mathrm{t} \mathrm{H}_{6}$ & $"$ \\
\hline 12. $\mathrm{LC}-\mathrm{t} \mathrm{H}_{7} \mathrm{~B}_{3} \mathrm{~F}_{0} \mathrm{R}_{1}(\mathrm{C}) \mathrm{V}_{0}$ & Tuulisuo, Pelso \\
\hline 13. $\mathrm{C}-\mathrm{t} \mathrm{H}_{5} \mathrm{~B}_{3} \mathrm{~F}_{0} \mathrm{R}_{1-2}(\mathrm{Phr} \mathrm{Eq}) \mathrm{V}_{0}$ & Kivisuo, Keuruu \\
\hline 14. $\mathrm{C}-\mathrm{t} \mathrm{H}_{8}$ & Aitoneva, Kihniö \\
\hline 15. Scorp- $\mathrm{t} \mathrm{H}_{1} \mathrm{~B}_{3} \mathrm{~F}_{0} \mathrm{R}_{0-1}(\mathrm{C} P \mathrm{Phr}) \mathrm{V}_{0}$ & Etelä-Lappi \\
\hline 16. $\mathrm{AC}-\mathrm{t} \mathrm{H}_{3} \mathrm{~B}_{3} \mathrm{~F}_{0} \mathrm{R}_{3}(\mathrm{C}) \mathrm{V}_{0}$ & " \\
\hline 17. $\mathrm{AC}-\mathrm{t} \mathrm{H}_{4}$ & $"$ \\
\hline 18. $\mathrm{AC}-\mathrm{t} \mathrm{H}_{6} \mathrm{~B}_{3} \mathrm{~F}_{0} \mathrm{R}_{2}(\mathrm{C}) \mathrm{V}_{0}$ & $"$ \\
\hline 19. $\mathrm{S}-\mathrm{t} \mathrm{H}_{2}$ & Aitoneva, Kihniö \\
\hline 20. $\mathrm{S}-\mathrm{t} \mathrm{H}_{3}$ & $"$ \\
\hline 21. $\mathrm{ErS}-\mathrm{t} \mathrm{H}_{4}$ & " \\
\hline 22. $\mathrm{ErS}-\mathrm{t} \mathrm{H}_{5}$ & " \\
\hline 23. $\mathrm{ErS}-\mathrm{t} \mathrm{H}_{6}$ & $\Rightarrow$ \\
\hline 24. $\mathrm{ErS}-\mathrm{t} \mathrm{H}_{6}$ & $"$ \\
\hline 25. $\mathrm{ErS}-\mathrm{t} \mathrm{H}_{6}$ & 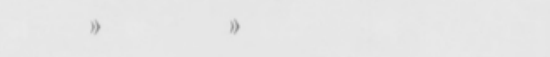 \\
\hline 26. $\mathrm{ErS}-\mathrm{t} \mathrm{H}_{7}$ & ") \\
\hline
\end{tabular}

Näytteet $1-7$ ovat eri pitkälle maatuneita rahkaturpeita etelä-Pohjanmaan eteläosasta, 8-14 eri pitkälle maatuneita sara-turpeita, 15-18 eri pitkälle maatuneita ruskosammalsaraturpeita Perä-Pohjolasta ja etelä-Lapista ja $19-2690 \mathrm{~cm}$ pitkä profiili etelä-Pohjanmaan eteläosasta käsittäen pääasiallisesti tupasvillarahkaturpeita. Edelläluetellun analyysimateriaalin lisäksi on bitumipitoisuuksia määritetty lukuisista turvenäytteistä keski- ja pohjois-Suomesta.

\section{Tuhka.}

Turpeen epäorgaaninen aines eli tuhka voidaan jakaa alkuperänsä perusteella primääriseen ja sekundääriseen tuhkaan. Ensinmainittu on turvetta muodostavista kasveista. Sekundäärisen tuhkan aineosat taas ovat joutuneet turpeeseen eri teitä sen synnyn ja kehityksen aikana. Raja näitten tuhkakomponenttien välillä ei kuitenkaan ole selvä eikä helposti vedettävissä. Turpeen tuhkan määrä ja kokoomus on jatkuvien vaihtelujen alainen. Kasvien maatuessa joutuvat niiden sisältämät epäorgaaniset aineet suureksi osaksi vähitellen vesiliukoiseen muotoon ja siirtyvät virtaavan veden tai korkeampien kasvien juuriston välityksellä pois alkuperäisestä paikastaan. Toiselta puolen liuenneet suolat voivat adsorboitua turpeeseen esim. ionivaihdon avulla tai saostua uusissa olosuhteissa esim. humaatteina tai hydrok- 
siideina ja jäädä siten turpeeseen. Niinpä esim. suon pinnassa nopeasti hajaantuvista orgaanisista aineista syntyvät hapot saattavat muodostaa veden sisältämien alkalien kanssa liukoisia suoloja, jotka joutuessaan syvemmälle voivat vaihtua maaalkaleihin ja rautaan y.m. Suota ympäröivistä kivennäismaista ja kallioperästä olevien minerogeenisten ainesten, etenkin kalsiumin on todettu adsorboituvan jo soitten reunaosiin niin, että keskustat jäävät Ca-köyhemmiksi (9). Tällaisen aineksen sijoittuminen riippuu valuvesien kulkusuunnista ja virtauksen voimakkuudesta. Tulvaveden mukana ja lumen sulaessa kulkeutuu myös minerogenistä ainesta lietteenä tulvanalaisille soille. Suot saavat epäorgaanista ainesta myös ilmakehän pölystä ja etenkin merenrannikon läheisyydessä sateen mukana meren tyrskyjen välityksellä ilmakehään joutuneista suoloista.

Turpeitten tuhkapitcisuuksia ja tuhkan kokoomusta on Suomessa tutkittu paljon erikoisesti viljavuuskysymyksien selvittämisen yhteydessä. Tällöin on todettu, että rahkaturpeet ovat yleensä tuhka-, typpi-, fosfori-, ja kalsiumköyhempiä kuin sara- ja ruskosammalturpeet ja sekaturpeet (10). Geologisessa tutkimuslaitoksessa on polttoturvesoiden inventoinnin yhteydessa tehty samoin turpeitten tuhkamäärityksiä. Tuloksia esitetään taulukossa 1, jonka SALmi (17) on julkaissut.

Taulukko 1. Turvelajiryhmien keskimääräinen tuhkapitoisuus. (Salmi 1947).

Table I. Average percentage of ash according to qualities of peat.

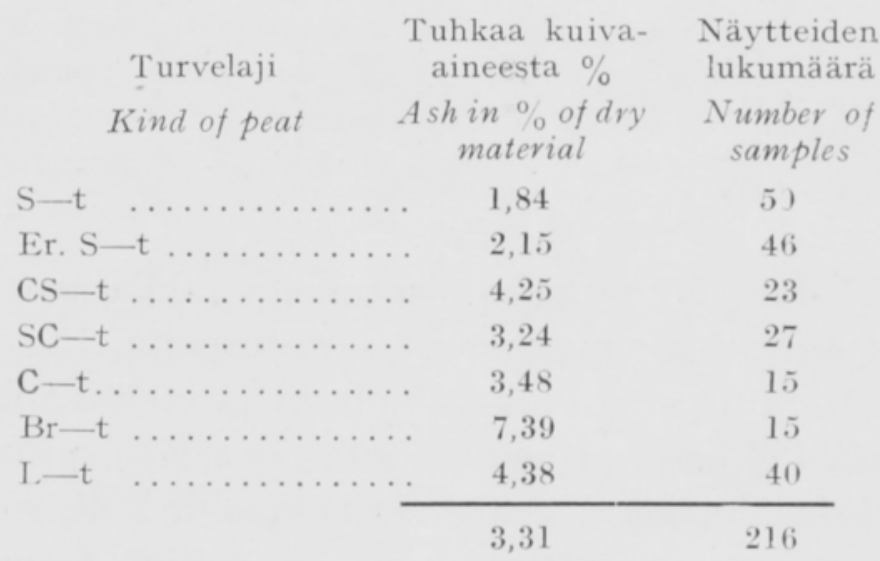

Jos ajatellaan tuhkan jakaantumista WAKSmanin ja STEwEnsin menetelmän eri fraktioihin, voidaan todeta, että tuhkan silikaattiaines vaikeimmin liukenevana jää hydrolysoitumattomaan jäännökseen, kun taas alkalisuolat ja vesiliukoinen osa muista suoloista joutuu vesiuutteeseen ja raudan, aluminiumin ja manganin hydroksidit ja oksihydraatit sekä niiden ja maa-alkalien fosfaatit ja karbonaatit y.m. happoihin liukenevina joutuvat happouutteisiin ja tällöin pääasiallisesti suolahappouutteeseen. Orgaanisiin komponentteihin sitoutuneen tuhka-aineksen sijoittuminen k.o. analyysissä on riippuvainen orgaanisen yhdistyksen luonteesta. Niinpä orgaanisten happojen suolat ovat usein veteen liukenevia, kun taas orgaaniset rikki- ja fosforiyhdistykset ovat enimmäkseen hyvin vaikealiukoisia.

Ylläesitetyn havainnollistamiseksi verrataan taulukossa 2 turpeiden eräitä tuhkafraktioita samojen näytteitten turveanalyysien fraktioitten tuhkapitoisuuksiin. Näytteet ovat keskimaatuneita $\left(\mathrm{H}_{5-7}\right)$ ErS-turpeita. 
Taulukko 2. Turpeiden eräiden tuhkafraktioiden vertailu turveanalyysien fraktioiden tuhkapitoisuuksiin.

Table 2. Comparison between the ash contents of two fractions of the peatanalysis and the fractions of the total ash of the peat.

\begin{tabular}{|c|c|c|c|c|c|}
\hline \multirow[b]{2}{*}{$\begin{array}{l}\text { Syv. cm } \\
\text { Depth } \mathrm{cm}\end{array}$} & \multicolumn{5}{|c|}{$\%$ kuiva-aineesta - In $\%$ of dry peat } \\
\hline & $\begin{array}{c}\text { Kokonais- } \\
\text { tuhka } \\
\text { Total } \\
\text { ash }\end{array}$ & $\begin{array}{c}\text { Tuhkaa } \\
\text { happoliuoksisissa } \\
\text { fraktioissa } \\
\text { Ash in the acid } \\
\text { fractions }\end{array}$ & $\begin{array}{c}\text { Seskvioksideita } \\
\text { turpeen tuhkassa } \\
\text { Sesquioxides } \\
\text { in the ash of } \\
\text { peat }\end{array}$ & $\begin{array}{l}\text { Tuhkaa hydroly- } \\
\text { soitumattomassa } \\
\text { jäännöksessä } \\
\text { Ash in the unhydro- } \\
\text { lyzable residue }\end{array}$ & $\begin{array}{c}\mathrm{SiO}_{2} \text { ja muuta } \\
\text { silikaattiainesta } \\
\text { turpeen tuhkassa } \\
\mathrm{SiO}_{2} \text { and other } \\
\text { silicate material } \\
\text { in the ash of peat } \\
\end{array}$ \\
\hline $28-33$ & 3,37 & 0,82 & 0,80 & 2,08 & 2,04 \\
\hline $38-43$ & 2,24 & 0,80 & 0,71 & 1,13 & 1,10 \\
\hline $48-53$ & 1,53 & 0,77 & 0,81 & 0,48 & 0,43 \\
\hline $65-70$ & 1,47 & 0,83 & 0,83 & 0,38 & 0,32 \\
\hline $75-80$ & 1,58 & 0,85 & 0,88 & 0,50 & 0,44 \\
\hline
\end{tabular}

Taulukko 3. Tuhkan jakaantuminen turveanalyysin eri fraktioihin.

Table 3. The ash contents of the various fractions expressed in percentage of the total ash content.

\begin{tabular}{|c|c|c|c|c|c|c|}
\hline \multirow[b]{2}{*}{$\begin{array}{l}\text { N:o } \\
\text { No. }\end{array}$} & \multirow[b]{2}{*}{$\begin{array}{c}\text { Syv. } \\
\text { m } \\
\text { Depth } \\
m\end{array}$} & \multirow[b]{2}{*}{$\begin{array}{c}\text { Turvelaji ja } \\
\text { maatuneisuus } \\
\text { Kind of peat and } \\
\text { humification }\end{array}$} & \multirow[b]{2}{*}{$\begin{array}{c}\text { Kokonais- } \\
\text { tuhka } \\
\text { Total } \\
\text { ash }\end{array}$} & \multicolumn{3}{|c|}{$\%$ kokonaistuhkasta - in $\%$ of total ash } \\
\hline & & & & $\begin{array}{c}\text { Tuhkaa } \\
\text { vesiliuoksessa } \\
\text { fraktiossa } \\
\text { Water soluble } \\
\text { ash }\end{array}$ & $\begin{array}{c}\text { Tuhkaa happoon } \\
\text { liukenevassa } \\
\text { fraktioissa } 1 \\
\text { Acid soluble } \\
\text { ash }\end{array}$ & $\begin{array}{c}\text { Tuhkaa } \\
\text { jäännöksessä } \\
\begin{array}{c}\text { Unsoluble } \\
\text { ash }\end{array}\end{array}$ \\
\hline 1 & $0,1 \longrightarrow 0,2$ & $\mathrm{~S}-\mathrm{t} \mathrm{H}_{2}$ & 1,82 & 19,2 & 14,3 & 66,5 \\
\hline 2 & $0,2-0,3$ & $\mathrm{ErS}-\mathrm{t} \mathrm{H}_{2}$ & 1,55 & 16,8 & 32,9 & 50,3 \\
\hline 3 & $1,0-1,5$ & $\mathrm{~S}-\mathrm{t} \mathrm{H}_{5}$ & 1,45 & 13,8 & 66,9 & 19,3 \\
\hline 4 & $1,5-2,0$ & $\mathrm{~S}-\mathrm{t} \mathrm{H}_{7}$ & 1,17 & 6,0 & 70,1 & 23,9 \\
\hline 5 & $2,0-2,5$ & $\mathrm{~S}-\mathrm{t} \mathrm{H}_{5}$ & 2,00 & 5,0 & 85,5 & 9,5 \\
\hline 6 & $1,1-1,3$ & $\mathrm{~S}-\mathrm{t} \mathrm{H}_{6}$ & 1,10 & 9,1 & 69,1 & 21,8 \\
\hline 7 & $1,2-1,7$ & $\mathrm{~S}-\mathrm{t} \mathrm{H}_{9}$ & 1,56 & 10,2 & 58,3 & 31,4 \\
\hline 8 & 0 & C. rostrata & 3,26 & 11,0 & 53,1 & 35,9 \\
\hline 9 & $0,6-0,7$ & $\mathrm{C}-\mathrm{t} \mathrm{H}_{4}$ & 2,79 & 5,7 & 62,4 & 31,9 \\
\hline 10 & 0,5 & $\mathrm{LC}-\mathrm{t} \mathrm{H}_{5}$ & 2,29 & 17,0 & 67,7 & 15,3 \\
\hline 11 & 1,0 & $\mathrm{LC}-\mathrm{t} \mathrm{H}_{6}$ & 4,08 & 4,4 & 76,0 & 19,6 \\
\hline 12 & $0,6-1.0$ & I. $\mathrm{C}-\mathrm{t} \mathrm{H}$ & 2,43 & 11,1 & 74,1 & 14,8 \\
\hline 13 & $2,7-2,9$ & $\mathrm{C}-\mathrm{t} \mathrm{H}_{5}$ & 3,79 & 6,9 & 68,3 & 24,8 \\
\hline 14 & 2,7 & $\mathrm{C}-\mathrm{t} \mathrm{H}_{8}$ & 4,48 & 4,7 & 75,0 & 20,3 \\
\hline 15 & 0,3 & $\mathrm{scorp}-\mathrm{tH}_{1}$ & 7,72 & 32,1 & 58,3 & 9,6 \\
\hline 16 & 0,3 & $\mathrm{AC}-\mathrm{t} \mathrm{H}_{3}$ & 6,41 & 12,8 & 71,9 & 15,3 \\
\hline 17 & 0,3 & $\mathrm{AC}-\mathrm{t} \mathrm{H}_{4}$ & 5,96 & 8,7 & 85,4 & 5,9 \\
\hline 18 & 0,3 & $\mathrm{AC}-\mathrm{t} \mathrm{H}_{6}$ & 7,39 & 7,6 & 86,3 & 6,1 \\
\hline 19 & $0,03-0,08$ & $\mathrm{~S}-\mathrm{t} \mathrm{H}_{2}$ & 2,41 & 40,7 & 4,1 & 55,2 \\
\hline 20 & $0,08-0,13$ & $\mathrm{~S}-\mathrm{t} \mathrm{H}_{3}$ & 3,38 & 28,7 & 27,8 & 43,5 \\
\hline 21 & $0,13-0,18$ & $\mathrm{ErS}-\mathrm{t} \mathrm{H}_{4}$ & 4,00 & 11,2 & 29,0 & 59,8 \\
\hline 23 & $0,38-0,43$ & $\mathrm{ErS}-\mathrm{t} \mathrm{H}_{6}$ & 2,24 & 11,2 & 38,4 & 50,4 \\
\hline 25 & $0,65-0,70$ & $\mathrm{ErS}-\mathrm{t} \mathrm{H}_{6}$ & 1,47 & 14,3 & 59,8 & 25,9 \\
\hline 26 & $0,75-0,80$ & $\mathrm{ErS}-\mathrm{t} \mathrm{H}_{7}$ & 1,58 & 13,3 & 55,1 & 31,6 \\
\hline
\end{tabular}

1) Saatu laskemalla, joten mukana on bitumiaineitten sisältämä hyvin pieni tuhkamäärä. The values obtained by calculation contain minute quantities of ash of bitumen. 
Taulukossa 3 esitetään käytetyn turveanalyysin eri fraktioihin joutuvat tuhkamäärät. Siinä on 18 ensimmäistä turvetta asetettu alekkain turvelajeittain siten, että maatuneisuus määrättynä hydrolysoitumattoman orgaanisen aineksen mukaan kasvaa alaspäin mentäessä. Näytteet 19-26, jotka muodostavat yhtenäisen profiilin, ovat sensijaan syvyysjärjestyksessä. Maatumisen suhteellisen suuruuden havaitsemiseksi on taulukkoon myös merkitty maatuneisuus määrättynä v. PosTin mukaan. Taulukosta käy ilmi, että pintaosan heikosti maatuneet turpeet $\left(\mathrm{H}_{1-\vartheta}\right)$ sisältävät yleensä huomattavasti runsaammin veteen liukenevaa ja niukemmin happoon liukenevaa tuhkaa kuin pitemmälle maatuneet turpeet. Selvää kuvaa siitä, miten maatumisen edistyminen ja turpeen syvyys vaikuttavat vesiliukoisen tuhkan määrään ei tämän suppean aineiston perusteella voi saada. Sitävastoin näyttää happoihin liukenevien tuhkakomponenttien määrä lisääntyvän syvemmälle mentäessä. Tähän lienee osaltaan vaikuttamassa happamuuden pieneneminen, mikä aiheuttaa esim. metallihydroksiidien saostumisen.

Suppea tutkimusmateriaali ei anna aihetta pitkälle meneviin tulkintoihin eri turvelajeja verrattaessa. Silmäänpistävää on kuitenkin ruskosammalsaraturpeitten alhainen liukenemattoman aineksen määrä, mikä on sopusoinnussa ANTTISEN (1) tekemien tutkimusten kanssa ruskosammalsaraturpeitten alhaisesta sekundäärisen tuhkan pitoisuudesta, joskin AnTTISEN saamat prosenttimäärät ovat korkeampia. Happoon liukenevaa tuhkaa sisältävät ruskosammalsaraturpeet usein myös huomattavasti enemmän kuin muut tutkitut turvelajit. Ruskosammalsaraturpeet ovatkin vähemmän happamia ja silloin on ymmärrettävää, että esim. hydroksidit saostuvat ja silikaatit liukenevat paremmin. KoтILAisen (11) mukaan ruskosammalturvesoitten boniteetti onkin korkeampi eri maatumisasteilla kuin muitten turvelajien. Sekaturpeita sisältävä profiili (n:o 19-26) ei sovellu vertailuun suuren sekundäärisen tuhkapitoisuutensa vuoksi.

Turpeitten tuhkapitoisuudella ja tuhkan kokoomuksella on suuri merkitys turpeitten teknillisessä käytössä. Se vaikuttaa polttoarvoihin, turpeen hajoamiseen, kuivatislausprosessiin, puolikoksiin, slakiin j.n.e. Tuhkan aineosat vaikuttavat katalyyttisesti orgaanisen massan hapettuessa ja voivat täten alentaa syttymispistettä ja lyhentää palamisaikaa. Turpeitten teknillisiin ominaisuuksiin etenkin rautahydroksidipitoisuus vaikuttaa suuresti (20). Tässä yhteydessä mainittakoon lisäksi Mrnssenin (13) havainto, ettei turpeen polttoarvo aina pienene tuhkamäärän lisääntyessä tasaisesti, vaan se pienenee suhteellisesti jyrkemmin. Näihin sekkoihin ei tämän tutkimuksen yhteydessä kuitenkaan lähemmin puututa.

\section{Bitumiaineet.}

Turpeen bitumiaineilla ymmärretään eetteriin, alkoholiin, bentsoliin y.m. orgaanisiin liuottimiin liukenevia aineita, jotka sisältävät pääasiallisesti vahoja, hartseja, rasvoja, öljyjä, alkaloideja, hiilivetyjä, amineita, pigmenttejä y.m. ja ovat peräisin turvetta muodostavista kasveista (Edelleen turvebitumi sisältää jo lueteltujen pääaineryhmien mukana n.s. seura-aineita kuten syani- ja virtsa-ainejohdannaisia, heterosyklisiä yhdisteitä j.n.e.). Bitumiaineisiin kohdistuvaa kemiallista 
tutkimusta on suoritettu hyvin runsaasti, johtuen niitten suuresta teknillisestä arvosta kemiallisen teollisuuden raaka-aineena.

Kasvit sisältävät vaihtelevia määriä bitumiaineita. Tämä riippuu pääasiallisesti kasvilajeista, mutta suuria vaihteluita on todettu myös saman lajin eri yksilöiden bitumiainepitoisuuksien välillä. Siihen ovat syynä m.m. ilmastolliset ja monet muut kasvupaikkatekijät sekä kasvien kehitysvaiheet. Paitsi kasvien bitumiainepitoisuuksiin vaikuttavat samat tekijät myös k.o. aineitten kemialliseen kokoomukseen. Tässä yhteydessä ei syvennytä bitumikomponenttien kemialliseen kokoomukseen eikä kokoomuksen muutoksiin kasvimateriaalin maatuessa. Mainittakoon kuitenkin, että turpeen eloperäisen aineen hajotessa vähitellen kaasuiksi ja vesiliukoisiksi yhdisteiksi, hajoavat rasvat ja öljyt suhteellisen nopeasti. Tällöin vapautuu happoja, jotka muodostavat suoloja ja säilyvät bitumissa kauan. Vahat ja hartsit ovat sitä vastoin vastustuskykyisiä, ja rikastuvat sen vuoksi turpeeseen maatumisen edistyessä. Nekään eivät kuitenkaan säily aivan muuttumattomina, koska ne sisältävät reaktiokykyisiä ryhmiä. Paitsi muuttuvia bitumiaineita sisältää kasvimateriaali myös kestäviä n.s. polymeri- eli stabilibitumeita kuten kutinia, suberinia ja sporopolleninia etupäässä itiöissä ja siitepölyssä.

Turvetta muodostavien kasvien ja turpeitten bitumiainepitoisuuksia ovat monet tutkijat määrittäneet $(13-15,20,23,24,26)$. Turpeitten bitumiaineitten määrittämiseksi on käytetty monia orgaanisia liuottimia yhdessä ja erikseen. Yleisimmän käytön on kuitenkin saanut bitumiaineiden uuttaminen hienoksijauhetusta turpeesta bentsolin ja alkoholin seoksella (1:1) sekä turveanalyysin yhteydessä erikoisesti WAKSMANin puolustama tapa uuttaa ensin eetterillä, poistaa sitten vesiliukoiset aineet ja sitten uuttaa alkoholilla. STADNikoffin (20) mielestä ei eetterillä ja alkoholilla saa turpeista kaikkea bitumia ja WAKsman puolestaan on sitä mieltä, että bentsoli liuottaa myös humushappoja. Tiтow (22) on tullut siihen tulokseen, ettei bentsoli-alkoholiseos liuota humiinihappoja, vaan niitten tapaisia huminihappohomologeja, otaksuttavasti estereitä. Kuitenkin paljon enemmän kuin mainittujen liuottimien valinta vaikuttaa turpeista eroitettavien bitumiaineitten määrään ja laatuunkin lämpötila ja paine uutettaessa sekä turpeen esikäsittely.

Lukuisten analyysien perusteella on voitu todeta, että eetteriin ja alkoholiin liukenevat ainemäärät vaihtelevat suuresti (n. $2-28 \%$ kuiva-aineesta), ja että eetteriin liukeneva ainemäärä on aina huomattavasti pienempi kuin alkoholiin liukeneva. Mitä enemmän turve sisältää alkoholiin liukenevaa ainetta, sitä enemmän siinä on yleensä myös eetteriin liukenevaa. ZAILERin ja WiLkin (26) tutkimusten mukaan sisältävät Sphagnum- ja Amblystegium-lajit $1-2 \%$ ja Carex-lajit 1,3-4,7\%, sekä rahkaturpeet $1-5,5 \%$ ja saraturpeet $2,3-6,3 \%$ eetteriin liukenevia aineita.

Tämän tutkimuksen yhteydessä on bentsolin ja alkoholin seoksella (1:1) suoritetuissa analyyseissä todettu, että ruskosammalsaraturpeet (5 näytettä, $\mathrm{H}_{4-6}$ ) sisältävät vähemmän bitumiaineita (keskim. 5,45\%) kuin rahka- ja saraturpeet. Ainakin keskimaatuneet saraturpeet (8 näytettä, $\mathrm{H}_{4-6}$ ) taas näyttävät olevan bitumiainepitoisempia (keskim. 11,89\%) kuin vastaavat rahkaturpeet.

Eri maatumisasteisten rahkasammalvaltaisten turpeitten keskimääräiseksi bitumipitoisuudeksi saatiin: 


\begin{tabular}{cccccc} 
Maatumisaste & \multicolumn{3}{c}{$\begin{array}{c}\text { näytteitten } \\
\text { luku }\end{array}$} & $\begin{array}{c}\text { Maatumisaste } \\
\text { Näytteitten } \\
\text { luku }\end{array}$ \\
$\mathrm{H}_{3}$ & $3.72 \%$ & 2 & $\mathrm{H}_{6}$ & $9.58 \%$ & 6 \\
$\mathrm{H}_{4}$ & $5.74 \%$ & 4 & $\mathrm{H}_{7}$ & $10.66 \%$ & 5 \\
$\mathrm{H}_{5}$ & $9.46 \%$ & 4 & $\mathrm{H}_{8}$ & $11.38 \%$ & 6 \\
& & & $\mathrm{H}_{9}$ & $15.46 \%$ & 3
\end{tabular}

Selvempi kuva turvelajiemme bitumiainepitoisuudesta saadaan kuitenkin turveanalyysillä. Monet tutkijat ovat julkaisseet eri turvelajien eetteriin ja alkoholiin liukenevia ainemääriä, jolloin uuttamiset on suoritettu useimmiten peräkkäin. WAKSMAN-STEWENSin (23) mukaisen turveanalyysin yhteydessä saadut alkoholiin liukenevat ainemäärät sitävastoin eivät sisällä veteen ja alkoholiin liukenevia aineita, koska vesiuutos on tehty eetteri- ja alkoholiuutosten välillä. Taulukossa 4 ilmoitetut turveanalyysillä saadut bitumiainemäärät on laskettu prosenteissa tuhkattomasta kuivasta turpeesta ja taulukossa 5 esitetään eräitten muitten tutkijoitten samalla menetelmällä saamia bitumiainemääriä prosenteissa kuiva-aineesta.

Taulukko 4. Muutamien Suomen turpeitten bitumiainepitoisuuksia (Waksmanin ja Stewensin analyysimenetelmä).

Table 4. Bitumen contents of scme kinds of Finish peat (Waksman and Stewens method of analysis)

\begin{tabular}{|c|c|c|c|c|c|}
\hline \multirow[b]{2}{*}{$\begin{array}{l}\text { N:o } \\
\text { No. }\end{array}$} & \multirow[b]{2}{*}{$\begin{array}{l}\text { Turvelaji ja } \\
\text { maatuneisuus } \\
\text { Kind of peat } \\
\text { humification }\end{array}$} & \multicolumn{3}{|c|}{$\%$ kuiva-aineesta - in $\%$ of ashrree dry material } & \multirow[b]{2}{*}{$\begin{array}{l}\text { Eetteriliukoista } \\
\text { bitumia \% koko } \\
\text { bitumista } \\
\text { Ether soluble in \% } \\
\text { of total bitumen }\end{array}$} \\
\hline & & $\begin{array}{c}\text { Eetteriin liukene- } \\
\text { vaa bitumia } \\
\text { Ether soluble } \\
\text { bitumen }\end{array}$ & $\begin{array}{c}\text { Alkoholiin liukene- } \\
\text { vaa bitumia } \\
\text { Alcohol soluble } \\
\text { bitumen }\end{array}$ & $\begin{array}{c}\text { Bitumia yhteensä } \\
\text { Total } \\
\text { bitumen }\end{array}$ & \\
\hline 1 & $\mathrm{~S}-\mathrm{t} \mathrm{H}_{2}$ & 1,44 & 2,83 & 4,27 & 33,7 \\
\hline 2 & $\mathrm{ErS}-\mathrm{t} \mathrm{H}_{2}$ & 2,17 & 3,22 & 5,39 & 40,2 \\
\hline 3 & $\mathrm{~S}-\mathrm{t} \mathrm{H}_{5}$ & 2,79 & 5,42 & 8.21 & 34,0 \\
\hline 4 & $\mathrm{~S}-\mathrm{t} \mathrm{H}_{7}$ & 3,66 & 4,62 & 8,28 & 44,2 \\
\hline 5 & $\mathrm{~S}-\mathrm{t} \mathrm{H}_{5}$ & 4,02 & 5,04 & 9,06 & 44,3 \\
\hline 6 & $\mathrm{~S}-\mathrm{t} \mathrm{H}_{6}$ & 4,43 & 5,23 & 9,66 & 45,8 \\
\hline 7 & $\mathrm{~S}-\mathrm{t} \mathrm{H}_{9}$ & 4,47 & 6,35 & 10,82 & 41,3 \\
\hline 8 & C. rostrata & 4,20 & 3,63 & 7,83 & 53,6 \\
\hline 9 & $\mathrm{C}-\mathrm{t} \mathrm{H}_{4}$ & 4,31 & 5,49 & 9,80 & 44,0 \\
\hline 10 & $\mathrm{LC}-\mathrm{t} \mathrm{H}_{5}$ & 5,29 & 5,70 & 10,99 & 48,1 \\
\hline 11 & $\mathrm{LC}-\mathrm{t} \mathrm{H}_{6}$ & 6,56 & 6,54 & 13,10 & 50,0 \\
\hline 12 & $\mathrm{LC}-\mathrm{t} \mathrm{H}_{7}$ & 7,04 & 5,93 & 12,65 & 55,7 \\
\hline 13 & $\mathrm{C}-\mathrm{t} \mathrm{H}_{5}$ & 6,08 & 5,48 & 11,56 & 52,6 \\
\hline 14 & $\mathrm{C}-\mathrm{t} \mathrm{H}_{8}$ & 4,87 & 5,30 & 10,17 & 47,9 \\
\hline 15 & Scorp-t $\mathrm{H}_{1}$ & 0,60 & 1,25 & 1,85 & 32,4 \\
\hline 16 & $\mathrm{AC}-\mathrm{t} \mathrm{H}_{3}$ & 1,27 & 3,56 & 4,83 & 26,2 \\
\hline 17 & $\mathrm{AC}-\mathrm{t} \mathrm{H}_{4}$ & 1,10 & 2,51 & 3,61 & 30,4 \\
\hline 18 & $\mathrm{AC}-\mathrm{t} \mathrm{H}_{6}$ & 2,03 & 3,85 & 5,88 & 34,5 \\
\hline
\end{tabular}


Taulukko 5. Eräitten tutkijoitten esittämiä turpeiden bitumiainemääriä.

Table 5. Bitumen content of various kinds of peat according to various scientists.

\begin{tabular}{|c|c|c|c|c|c|}
\hline \multirow{2}{*}{$\begin{array}{c}\text { Turvelaji ja } \\
\text { maatuneisuus } \\
\text { Kind of peat and } \\
\text { humification }\end{array}$} & \multicolumn{3}{|c|}{$\begin{array}{c}\% \text { kuiva-aineesta } \\
\text { In } \% \text { of dry material }\end{array}$} & \multirow{2}{*}{$\begin{array}{c}\text { Eetteriliukois- } \\
\text { ta bitumia \% } \\
\text { koko bitumista } \\
\text { Ether soluble } \\
\text { in \% of tolal } \\
\text { bitumen }\end{array}$} & \multirow[b]{2}{*}{$\begin{array}{l}\text { Määrittännyt } \\
\text { Estimated by }\end{array}$} \\
\hline & $\begin{array}{c}\text { Eetteriin } \\
\text { tiukenevaa } \\
\text { bitumia } \\
\text { Ether soluble } \\
\text { bitumen }\end{array}$ & $\begin{array}{c}\text { Alkoholiin } \\
\text { liukenevaa } \\
\text { bitumia } \\
\text { Alcohol } \\
\text { soluble } \\
\text { bitumen } \\
\end{array}$ & $\begin{array}{c}\text { Bitumia } \\
\text { yhteensä } \\
\text { Total } \\
\text { bitumen }\end{array}$ & & \\
\hline $\mathrm{S}-\mathrm{t} \mathrm{H}_{2-3}$ & 3,53 & 4,56 & 8,09 & 43,6 & Kivinen \\
\hline $\mathrm{S}-\mathrm{t} \mathrm{H}_{3}$ & 1,3 & 1,7 & 3,0 & 43,3 & GAARDNER, Alvsaker \\
\hline $\mathrm{ErS}-\mathrm{t} \mathrm{H}$ & 3,6 & 4,0 & 7,6 & 47,4 & $"$ \\
\hline $\mathrm{C}-\mathrm{t} \mathrm{H}_{2-3}$ & 4,73 & 5,10 & 9,83 & 48,1 & KIVINEN \\
\hline $\mathrm{AC}-\mathrm{t} \mathrm{H}_{3}$ & 2,76 & 5,35 & 7,11 & 38,8 & " \\
\hline$A-t$ & 0,49 & 1,04 & 1,53 & 32,0 & Waksman, SteWENS \\
\hline $\mathrm{S}$ - $\mathrm{t}$ heikosti maat. & 2,55 & 5,24 & 7,79 & 32,7 & Feustel, Byfrs \\
\hline $\mathrm{S}$-t vähän maat & 2,39 & 4,78 & 7,17 & 33,3 & ) \\
\hline $\mathrm{S}-\mathrm{t}$ & 2,83 & 4,95 & 7,78 & 36,4 & " \\
\hline $\mathrm{S}-\mathrm{t}$ & 3,27 & 516 & 8,43 & 38,8 & $\Rightarrow$ \\
\hline $\mathrm{S}-\mathrm{t}$ & 1,98 & 4,25 & 6,23 & 31,8 & ") \\
\hline $\mathrm{S}$-t ositt. maat. & 2,39 & 5,25 & 7,64 & 31,3 & " \\
\hline $\mathrm{S}-\mathrm{t}$ & 3,25 & 6,31 & 9,56 & 34,0 & $"$ \\
\hline $\mathrm{S}$ - - t keski maat. & 5,18 & 3,87 & 9,05 & 57,2 & WAKSMAN, STEWENS \\
\hline $\mathrm{S}-\mathrm{t} \quad \Rightarrow$ & 4,28 & 3,52 & 7,80 & 54,9 & $"$ \\
\hline $\mathrm{S}-\mathrm{t}, \quad "$ & 5,17 & 3,72 & 8,89 & 58,2 & " \\
\hline $\mathrm{C}$ - $\mathrm{t}$ vähän maat. & 0,60 & 1,89 & 2,49 & 24,1 & " \\
\hline $\mathrm{C}-\mathrm{t}$ ositt. maat. & 0,55 & 2,01 & 2,56 & 21,5 & " \\
\hline $\mathrm{C}$ - t voimakk. maat. & 0,70 & 2,27 & 2,97 & 23,6 & " \\
\hline
\end{tabular}

Taulukko 4:ssä esitetyt arvot vahvistavat edelläesitettyä käsitystä turpeiden bitumiainepitoisuuksista. Ruskosammalsaraturpeet sisältävät huomattavasti vähemmän bitumiaineita kuin rahka- ja saraturpeet. Saraturpeet taas näyttävät tämänkin taulukon mukaan sisältävän enemmän bitumiaineita kuin rahkaturpeet. Edelleen tukee taulukko ZAILERin ja WiLkin (26) tekemää havaintoa, että rahkaturpeitten bitumiainepitoisuus kasvaa maatumisen edistyessä selvemmin kuin saraturpeitten ja että siis edellisten bitumiaineet ovat laadultaan pysyvämpiä. Jos tarkastetaan eri turvelajien eetteriin ja alkoholiin liukenevien ainemäärien keskinäistä suhdetta, huomataan taulukosta 4, että eetteriin liukenee k.o. analyysimenetelmällä saadusta bitumiainemäärästä ruskosammalsaraturpeista vähiten (keskim. 30,9\%), sitten rahkaturpeista (keskim. 40,5\%) ja eniten saraturpeista (keskim. 50,8\%). Taulukosta 5, joka on koottu ja laskettu samaa analyysimenetelmää käyttäneitten tutkijoitten analyysituloksista, huomataan, että Skandinavian turvemateriaalia käyttäneet tutkijat ovat tulleet samaan tulokseen, kun taas amerikkalaiset tutkijat ovat saaneet S- ja C-turpeista jyrkästi erilaisia tuloksia. Kuten taulukosta käy ilmi sisältävät WAKsmaxin tutkimat saraturpeet vähiten ja rahkaturpeet eniten eetteriin liukenevia bitumiaineita. 
Edelläesitetyllä on erikoisesti merkitystä polttoturpeitten laatua ja ominaisuuksia tutkittaessa. Minssen (13) jo viittasi bitumiaineitten vaikutukseen turpeitten polttoarvoihin. Hän totesi myös, että bitumiaineitten laatu vaihtelee suuresti vieläpä samassa profiilissa saman turvelajin eri tavalla maatuneissa turpeissa. Hän ilmoittaa heikosti maatuneen rahkaturpeen alkoholiin liukenevien aineitten polttoarvoksi $7838 \mathrm{kkal} / \mathrm{kg}$ ja saman profiilin enemmän maatuneen rahkaturpeen alkoholiin liukenevien aineitten polttoarvoksi $8602 \mathrm{kkal} / \mathrm{kg}$. Tämä johtunee siitä, että varsinkin energiaköyhemmät veteen ja alkoholiin liukenevat bitumiaineet hajoavat nopeammin maatumisen edistyessä kuin muut bitumiaineet. Tämän tutkimuksen yhteydessä saatiin hyvin maatuneen rahkaturpeen eetteriin liukenevan bitumiaineksen kalorimetriarvoksi $9311 \mathrm{kkal} / \mathrm{kg}$ ja keskimaatuneen saraturpeen eetteriin liukenevan bitumiaineksen kalorimetriarvoksi $9346 \mathrm{kkal} / \mathrm{kg}$. Kun turpeista oli uutettu eetteriin ja veteen liukenevat aineet saatiin samojen turpeitten alkoholiin liukenevien aineitten kalorimetriarvoiksi $7434 \mathrm{kkal}$ ja $7365 \mathrm{kkal} / \mathrm{kg}$. Kun katsotaan edellä tutkittujen turvelajien polttoarvoja edelläesitetyn bitumitutkimuksen valossa, huomataan, että yhtenä tärkeänä syynä meikäläisten sara-turpeitten korkeisiin polttoarvoihin on k.o. turvelajien suuri bitumiainemäärä ja bitumin kokoomus, joka on erilainen kuin rahka- ja ruskosammalsaraturpeilla. Bitumiaineitten määrä ja laatu on siis suuresti riippuvainen turvelajeista ja soiden geologisesta kehityksestä. Tämä on otettava huomioon paitsi polttoturvetutkimuksissa myös turvevahojen ja hartsien eristystä ja jalostusta tutkittaessa.

\section{Turpeitten mu orgaaninen kokoomus.}

Turpeitten sisältämät orgaaniset aineet jakaa Souci (19) seuraavasti:

I. Kasvien sisältämät rakennusaineet.

1. Valkuaisaineet.

2. Selluloosa.

3. Mono- ja disakkariidit.

4. Hemiselluloosat (pentosanit, metyl-pentosanit, heksosani-pentosanit, heksosanit).

5. Pektiiniaineet.

6. Ligniini.

7. Rasvat.

8. Protobitumit

a. Ekstrakti-protobitumit (hajoamattomat vahat ja hartsit).

b. Polymerprotobitumit (hajoamattomat sporopollenini, cutini, suberini sekä osittain vahat ja hartsit).

9. Parkkiaineet.

II. Maatumisen tulokset.

1. Humusaineet

a. huminihapot (humus- ja hymatomelanihapot).

b. humoligniinihapot.

c. huminit (NaOH liukenemattomat huminihapot).

2. Fulvohapot ja humusseuralaisaineet.

3. Phlobaphenit (peräisin parkkiaineista). 
Taulukko 6. Ainemäärien jakaantuminen eri analyysifraktioihin ilmaistuna prosenteissa kuiva-aineesta.

Table 6. Fractions of the analysis in percentage of dry material.

\begin{tabular}{|c|c|c|c|c|c|c|c|}
\hline $\begin{array}{l}\text { N:o } \\
\text { No. }\end{array}$ & $\begin{array}{l}\text { Syv. } \\
\text { m } \\
\text { Depth } \\
m\end{array}$ & $\begin{array}{c}\text { Turvelaji ja } \\
\text { maatuneisuus } \\
\text { Kind of peat and } \\
\text { humification }\end{array}$ & $\begin{array}{l}\text { Bitumi- } \\
\text { aineet } \\
\text { Bitumen }\end{array}$ & $\begin{array}{c}\text { Vesiliukoi- } \\
\text { nen fraktio } \\
\text { Water } \\
\text { soluble } \\
\text { fraktion } \\
\end{array}$ & $\begin{array}{l}2 \% \text { HCl- } \\
\text { fraktio } \\
\text { Soluble in } \\
2 \text { per cent } \\
\text { HCl } \\
\end{array}$ & $\begin{array}{c}80 \% \\
\mathrm{H}_{2} \mathrm{SO}_{4^{-}} \\
\text {fraktio } \\
\text { Soluble in } \\
80 \text { per cent } \\
\mathrm{H}_{2} \mathrm{SO}_{1} \\
\end{array}$ & $\begin{array}{c}\text { Hydroly- } \\
\text { soitumaton } \\
\text { jäännös } \\
\text { Unhydroly- } \\
\text { zable } \\
\text { residue } \\
\end{array}$ \\
\hline 1 & $0,1-0,2$ & $\mathrm{~S}-\mathrm{t} \mathrm{H}_{2}$ & 4,19 & 5.84 & 54,23 & 19,54 & 16,20 \\
\hline 2 & $0,2-9,3$ & $\mathrm{ErS}-\mathrm{t} \mathrm{H}_{2}$ & 5,31 & 9,06 & 49,67 & 20,09 & 15.87 \\
\hline 3 & $1,0-1,5$ & $\mathrm{~S}-\mathrm{t} \mathrm{H}_{5}$ & 8,09 & 2,90 & 39,94 & 20,47 & 28,60 \\
\hline 4 & $1,5-2,0$ & $\mathrm{~S}-\mathrm{t} \mathrm{H}_{7}$ & 8,19 & 2,50 & 41,02 & 18,67 & 29,62 \\
\hline 5 & $2,0-2,5$ & $\mathrm{~S}-\mathrm{t} \mathrm{H}_{5}$ & 8,88 & 3,58 & 37,21 & 15,72 & 34,61 \\
\hline 6 & $1,1-1,3$ & $\mathrm{~S}-\mathrm{t} \mathrm{H}_{6}$ & 9,55 & 5,18 & 34,51 & 15,66 & 35,10 \\
\hline 7 & $1,2-1,7$ & $\mathrm{~S}-\mathrm{t} \mathrm{H}_{9}$ & 10,65 & 3,24 & 30,34 & 10,21 & 45,56 \\
\hline 8 & 0 & resent C. rostr. & 7,57 & 5,87 & 40,29 & 27,42 & 18,85 \\
\hline 9 & $0,6-9,7$ & $\mathrm{C}-\mathrm{t} \mathrm{H}_{4}$ & 9,53 & 1,89 & 32,26 & 14,70 & 41,62 \\
\hline 10 & 0,5 & $\mathrm{LC}-\mathrm{t} \mathrm{H}_{5}$ & 10,74 & 2,73 & 32,01 & 13,22 & 41,30 \\
\hline 11 & 1,0 & $\mathrm{LC}-\mathrm{t} \mathrm{H}_{6}$ & 12,56 & 2,67 & 26,50 & 7,63 & 50,64 \\
\hline 12 & $0,6-1,0$ & $\mathrm{LC}-\mathrm{t} \mathrm{H}_{7}$ & 12,34 & 4,11 & 21,97 & 10.07 & 51,51 \\
\hline 13 & $2,7-2,9$ & $\mathrm{C}-\mathrm{t} \mathrm{H}_{5}$ & 11,12 & 1,36 & 23,52 & 10,35 & 53,65 \\
\hline 14 & 2,7 & $\mathrm{C}-\mathrm{t} \mathrm{H}_{8}$ & 9,71 & 1,57 & 25,51 & 8,48 & 54,73 \\
\hline 15 & 0,3 & Scorpidium -t $\mathrm{H}_{1}$ & 1,70 & 8,50 & 36,88 & 15,96 & 36,96 \\
\hline 16 & 0,3 & $\mathrm{AC}-\mathrm{t} \mathrm{H}_{3}$ & 4,51 & 4,88 & 41,61 & 11,28 & 37,72 \\
\hline 17 & 0,3 & $\mathrm{AC}-\mathrm{t} \mathrm{H}_{4}$ & 3,39 & 2,46 & 41,43 & 12,47 & 40,25 \\
\hline 18 & 0,3 & $\mathrm{AC}-\mathrm{t} \mathrm{H}_{6}$ & 5,45 & 3,50 & 41,76 & 7,69 & 41,60 \\
\hline 19 & $0,03-0,08$ & $\mathrm{~S}-\mathrm{t} \mathrm{H}_{2}$ & 5,20 & 7,29 & 52,12 & 16,07 & 19,32 \\
\hline 21 & $0,13-0,18$ & $\mathrm{ErS}-\mathrm{t} \mathrm{H}_{4}$ & 5,42 & 6,83 & 45,43 & 19,56 & 22,76 \\
\hline 20 & $0,08-0,13$ & $\mathrm{~S}-\mathrm{t} \mathrm{H}_{3}$ & 4,35 & 6,51 & 52,12 & 12,43 & 24,59 \\
\hline 24 & $0,33-0,38$ & $\mathrm{ErS}-\mathrm{t} \mathrm{H}_{5}$ & 9,37 & 3,88 & 38,77 & 21,21 & 26,77 \\
\hline 26 & $0,48-0,53$ & $\mathrm{ErS}-\mathrm{t} \mathrm{H}_{6}$ & 11,13 & 3,92 & 32,84 & 18,37 & 33,74 \\
\hline 25 & $0,38-0,43$ & $\mathrm{ErS}-\mathrm{t} \mathrm{H}_{6}$ & 11,10 & 4,16 & 31,10 & 18,90 & 34,74 \\
\hline 28 & $0,70-0,80$ & $\mathrm{ErS}-\mathrm{t} \mathrm{H}_{7}$ & 13,59 & 6,58 & 28,99 & 14,81 & 36,03 \\
\hline 27 & $0,65-0,70$ & $\mathrm{ErS}--\mathrm{t} \mathrm{H}_{6}$ & 10,29 & 4,41 & 30,48 & 17,74 & 37,08 \\
\hline
\end{tabular}

4. Bitumit

a. Ekstraktibitumit (fossiloituneet vahat ja hartsit).

b. Polymeribitumit 1. stabilibitumit (cutini j.n.e.)

5. Uronihappokompleksit, pentosanit (pektiniaineista).

6. Aminohapot ja muut valkuaisaineitten hajoamistulokset.

7. Valkuaisaineet, jotka mikro-organismit ovat syntetisoineet.

Tämä jako osoittaa kuinka monipuolisen ja vaihtelevan materiaalin kanssa ollaan tekemisissä turvekemiallisissa tutkimuksissa. Käytetyn analyysimenetelmän vesiliukoiseen fraktioon joutuvat orgaanisista aineista pääasiallisesti pektiiniaineet, parkkiaineet, tärkkelys, sokerit, alemmat eriarvoiset rasvahapot ja niitten vesiliukoiset suolat, aminohappoja j.n.e. $2 \%$-suolahappoon liukenevaan fraktioon joutuvat hemiselluloosa (heksosanit ja pentosanit), uronihappoyhdisteitä ja proteineja. $80 \%$ rikkihappofraktion pääosan muodostavat selluloosa ja uronihappo- 
yhdisteet sekä pieni osa proteineista. Hydrolysoitumattomaan jäännökseen taas jäävät ligniini ja sen tapaiset yhdisteet sekä hapoilla hydrolysoitumattomia typpiyhdisteitä. Kaikkiin yllämainittuihin fraktioihin joutuu lisäksi kemiallisesti vähemmän tunnettuja, eri pitkälle muuttuneita n.s. huminihappoja (4). Niistä tutkijoista, jotka ovat menetelmää kritisoineet, mainittakoon tässä vain STADNIKOFF (20), joka huomauttaa, että WAKsmanin menetelmää käytettäessä osa bitumiaineista jää ligniinifraktioon ja osa pektiiniaineista jää suolahappoon liukenevaan hemiselluloosafraktioon. Koska tässä yhteydessä tulee pääasiallisesti kysymykseen turpeitten vertaileva tutkimus, tuntuvat menetelmän mahdolliset heikkoudet vähemmän. Mainittakoon, että menetelmä jakaa kemiallisesti turvemateriaalin polttoturvetutkimuksen kannalta tärkeisiin energeettisiin pääryhmiin.

Taulukossa 6 esitetään turvemateriaalin jakaantuminen analyysin pääfraktioihin laskettuna prosenteissa kuiva-aineesta. Turpeet on järjestetty taulukkoon turvelajeittain siten, että hapoilla hydrolysoitumattoman bitumivapaan orgaanisen aineksen määrä kasvaa. Viimemainitun jäännöksen kasvamista voidaan nimittäin pitää eräänlaisena, samasta lähtöaineesta peräisin olevan, anaerobisissa olosuhteissa maatuneen turpeen maatumisen edistymisen mittana ja, kuten myöhemmin tullaan huomaamaan, polttoturpeen lämpöarvoon ratkaisevasti vaikuttavana tekijänä. Viimeisenä taulukossa on joukko Eriophorum-pitoisia rahkaturpeita, jotka käsitellään eri ryhmänä, koska ne ovat peräisin samasta profiilista ja analysoidut epätäydellisemmin, kuten alussa on mainittu.

Taulukossa 7 on esitetty analyysituloksia laskettuna prosenteissa tuhkattomasta materiaalista. Taulukossa esitetyllä A-fraktiolla tarkoitetaan happoihin liuennutta orgaanisen aineen määrää, joka ei ole hemiselluloosaa, selluloosaa, eikä proteiineja vaan pääasiallisesti huminihappoja. „Vapaa raakaproteiini»-sarakkeeseen on laskettu happo- ja vesiliukoisiin fraktioihin joutuvaa typpimäärää vastaava proteiini. Typpi- ja valkuaisainekysymys on jätetty teknilliselle turvetutkimukselle vähempiarvoisena tässä yhteydessä yksityiskohtaisemmin käsittelemättä.

Edellä on jo puhuttu turvebitumista, joten siihen ei enää tuloksia taulukkojen valossa tarkastettaessa ole syytä puuttua. Sensijaan lienee paikallaan kiinnittää huomiota hiilihydraatteihin ja hydrolysoitumattomaan jäännökseen. Useat tutkijat $(3,6,8,15,23)$ ovat tehneet vastaavanlaisia analyysejä ja todenneet tiettyjä säännönmukaisuuksia tuloksissa. Havainnoissa on kuitenkin joukko eroavaisuuksia, mikä onkin ymmärrettävää, koska tutkimuskohteet on otettu eri puolilta maapalloa, eikä maatuneisuus ja turvelajimääritys eikä tutkimusmetodiikka ole aina ollut yhtenäistä. Koska lisäksi analyysi on verraten suuritöinen, ei yleensä tutkimusmateriaali ole ollut riittävän suuri peittämään tilapäisiä, usein sekundäärisien tekijöitten aiheuttamia vaihteluja tuloksissa. Tämänkään tutkimuksen yhteydessä ei ole voitu välttää monia epäkohtia, mutta eliminoimalla pois mahdollisimman paljon vaihtelevia tekijöitä tarkalla turvelajimäärityksellä ja alueellistamalla tutkimus ilmastollisten ja geologisten vaihtelujen välttämiseksi, on yritetty antaa tarkempi kuva eräitten turpeittemme kemiallisesta kokoomuksesta. Eri tutkijoitten tekemien havaintojen perusteella tiedetään, että rahkaturpeet sisältävät yleensä eniten hemiselluloosaa ja enemmän selluloosaa kuin esim. saraturpeet, joitten selluloosa- 
Taulukko 7. Analyysituloksia laskettuna prosenteissa tuhkattomasta kuiva-aineesta.

Table 7. Results of analyses in percentage of dry askfree material.

\begin{tabular}{|c|c|c|c|c|c|c|c|c|c|}
\hline $\begin{array}{l}\text { N:o } \\
\text { No. }\end{array}$ & $\begin{array}{c}\cdot \text { Syv. } \\
\text { m } \\
\text { Depth } \\
m\end{array}$ & $\begin{array}{l}\text { Turvelaji ja } \\
\text { maatuneisuus } \\
\text { Kind of peat } \\
\text { humification }\end{array}$ & 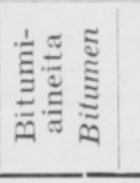 & $\begin{array}{l}\text { Vesiliukoisia } \\
\text { org. aineita } \\
\text { Water soluble } \\
\text { org. material }\end{array}$ & 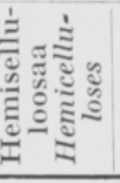 & 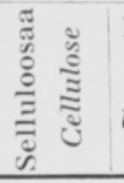 & $\begin{array}{c}\text { Hydrolysoitu- } \\
\text { matonta org. } \\
\text { jäännöstă } \\
\text { Unhydrolyzable } \\
\text { org. residue }\end{array}$ & 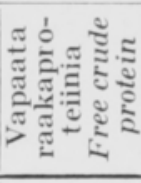 & 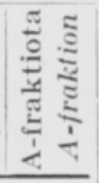 \\
\hline 1 & $0,1-0,2$ & $\mathrm{~S}-\mathrm{t} \mathrm{H}_{2}$ & 4,27 & 5,59 & 35,91 & 18,43 & 15,27 & 3,12 & 18,22 \\
\hline 2 & $0,2-0,3$ & $\mathrm{ErS}-\mathrm{tH}$ & 5,39 & 8,94 & 29,94 & 19,16 & 15,33 & 4,70 & 17,48 \\
\hline 3 & $1,0-1,5$ & $\mathrm{~S}-\mathrm{t} \mathrm{H}_{5}$ & 8,21 & 2,74 & 25,80 & 17,98 & 28,74 & 2,86 & 13,92 \\
\hline 4 & $1,5-2,0$ & $\mathrm{~S}-\mathrm{t} \mathrm{H}_{7}$ & 8,28 & 2,46 & 24,64 & 18,11 & 29,69 & 2,47 & 14,48 \\
\hline 5 & $2,0-2,5$ & $\mathrm{~S}-\mathrm{t} \mathrm{H}_{5}$ & 9,06 & 3,55 & 23,39 & 14,43 & 35,12 & 2,56 & 12,02 \\
\hline 6 & $1,1-1,3$ & $\mathrm{~S}-\mathrm{t} \mathrm{H}_{6}$ & 9,66 & 5,14 & 24,45 & 15,44 & 35,23 & $4,9 \tilde{5}$ & 5,38 \\
\hline 7 & $1,2-1,7$ & $\mathrm{~S}-\mathrm{t} \mathrm{H}_{9}$ & 10,82 & 3,13 & 18,16 & 3,33 & 45,78 & 3,87 & 15,79 \\
\hline 8 & 0 & resent.C. rostr. & 7,83 & 5,69 & 18.03 & 25,63 & 18,27 & 2,65 & 22,71 \\
\hline 9 & $0,6-0,7$ & $\mathrm{C}-\mathrm{t} \mathrm{H}_{4}$ & 9,80 & 1,78 & 18,61 & 9,96 & 41,90 & 3,51 & 14,57 \\
\hline 10 & 0,5 & $\mathrm{LC}-\mathrm{t} \mathrm{H}_{5}$ & 10,99 & 2,39 & 18,27 & 6,94 & 41,91 & 8,44 & 12,00 \\
\hline 11 & 1,0 & $\mathrm{LC}-\mathrm{t} \mathrm{H}_{6}$ & 13,10 & 2,60 & 7,16 & 6,49 & 51,96 & 12,51 & 6,24 \\
\hline 12 & $0,6-1,0$ & $\mathrm{LC}-\mathrm{t} \mathrm{H}_{7}$ & 12,65 & 3,94 & 10,08 & 5,94 & 52,42 & 8,46 & 6,70 \\
\hline 13 & $2,7-2,9$ & $\mathrm{C}-\mathrm{t} \mathrm{H}_{5}$ & 11,56 & 1,14 & 10,75 & 8,82 & 54,79 & 10,39 & 2,80 \\
\hline 14 & 2,7 & $\mathrm{C}-\mathrm{t} \mathrm{H}_{8}$ & 10,17 & 1,42 & 13,15 & 4,85 & 56,34 & 11,51 & 2,94 \\
\hline 15 & 0,3 & Scorp- $\mathrm{tH}_{1}$ & 1,85 & 6,52 & 23,58 & 15,80 & 39,25 & 7,17 & 6,56 \\
\hline 16 & 0,3 & $\mathrm{AC}-\mathrm{t} \mathrm{H}_{3}$ & 4,83 & 4,34 & 22,71 & 8,55 & 39,26 & 12.01 & 9,18 \\
\hline 17 & 0,3 & $\mathrm{AC}-\mathrm{t} \mathrm{H}_{4}$ & 3,61 & 2,06 & 23,06 & 8,09 & 42,43 & 10,10 & $11,2 \mathrm{~s}$ \\
\hline 18 & 0,3 & $\mathrm{AC}-\mathrm{t} \mathrm{H}_{6}$ & 5,88 & 3,17 & 18,12 & 3,30 & 44,43 & 14,17 & 11,68 \\
\hline
\end{tabular}

prosentti on hyvin alhainen. Edelleen tiedetään, että turpeitten selluloosapitoisuus on paljon pienempi kuin turvetta muodostavien kasvien ja se pienenee maatumisen edistyessä kuten hemiselluloosapitoisuuskin. Vesiliukoisia aineita on S-turpeitten myös havaittu sisältävän enemmän kuin useimpien muiden turvelajien.

Kun tarkastetaan Suomen turvelajien summittaista kemiallista kokoomusta ensin taulukosta 6 ja tehdään sen perusteella graafinen esitys tuloksista (kuva 1), voidaan nähdä puhtaitten rahka- ja Eriophorum-pitoisten rahkaturpeitten kokoomuksen muuttumisen tendenssi (Kuvassa on bitumifraktion käyrää piirrettäessä otettu huomioon myös aikaisemmin siv. 88 esitetyt bentsolin ja alkoholin seoksella saadut bitumipitoisuudet). Siinä kiinnittää huomiota $\mathrm{H}_{2} \mathrm{SO}_{4}$-fraktion loiva ja $\mathrm{HCl}$ fraktion jyrkkä lasku, jäännösfraktion selvä nousu ja bitumikäyrän muoto. Jos verrataan tuloksia MALIUTiNin (25) samantapaiseen käyrästöön voidaan panna merkille erikoisesti bitumi- ja jäännöskäyrien yhtäläisyys (Selluloosakäyrän erilaisuus johtunee MaLiUtinin käyttämästä menetelmästä, joka ei WAKsmanin mukaan anna oikeita selluloosapitoisuuksia). Bitumikäyrän alkuosan muotoon vaikuttanee rasvojen ja öljyjen nopea hajoaminen.

Tutkittu sara- ja ruskosammalsaraturvemateriaali ei valitettavasti riitä vastaavanlaisten käyrästöjen piirtämiseen. Taulukkojen 6 ja 7 arvoista käy kuitenkin selvästi ilmi, että eri fraktioihin joutuvien ainemäärien vaihteluilla saraturpeessa 


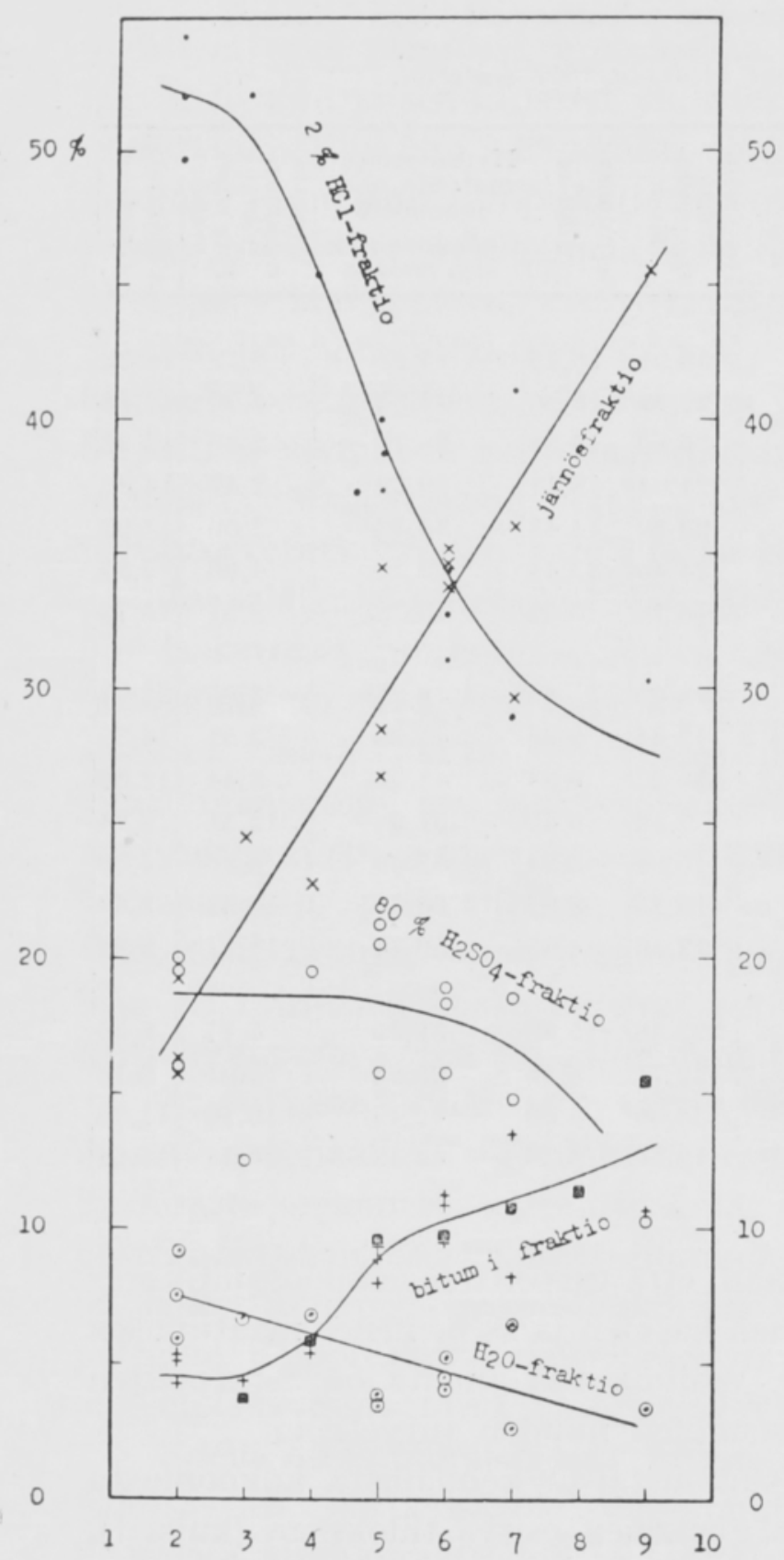

Kuva 1. Maatumisaste. S- ja ErS-turpeitten kemiallisen kokoomuksen muuttumisen tendenssi maatumisasteen suuretessa.

Fig. 1. Stage of humification. Diagram to illustrate the trend of changes in the chemical composition of $S$ - and ErS-peat with the humufication. maatumisen edistyessä on sama tendenssi kuin rahkaturpeilla. Huomattavimpana ja teknillisessä mielessä tärkeimpänä eroavaisuutena on pidettävä saraturpeitten selvästi korkeampaa hapoilla hydrolysoitumattoman jäännöksen määrää, joka vaihtelee analyyseissä $41,30-54,73 \%$ kuivaaineesta keskiarvon ollessa $48,91 \%$ (taulukko 8). Rahkaturpeitten vastaavat prosenttiluvut ovat $15,87-45,56 \%$ ja keskiarvo $31,62 \%$. Ruskosammalsaraturpeitten hapoilla hydrolysoitumattoman aineksen määrää on vaikeata verrata edellisiin, koska tutkittu aineisto on niukka.

Jos verrataan taulukkojen perusteella edelleen sara- ja ruskosammalsaraturpeitten hapoilla hydrolysoituvia ainemääriä rahkaturpeitten vastaaviin analyysituloksiin, voidaan todeta paitsi yleinen k.o. fraktioitten pieneneminen maatumisen edistyessä myös yleensä alhaisemmat prosenttimäärät. $2 \%$ suolahappofraktion ainemäärien keskiarvoksi rahkaturpeille saadaan $39,54 \%$ ja saraturpeille $26,96 \%$, ja $80 \%$ rikkihappofraktion keskiarvoksi rahkaturpeille $16,71 \%$ ja saraturpeille 10,74\% (Keskiarvolaskuista taulukkoon 8 on jätetty pois näyte n:o 2 , näyte n:o 8 ja profiili19-26, jotta saataisiin k.o. turvelajeille paremmin toisiinsa verrattavia arvoja, ja jotta S-materiaali olisi mahdollisimman puhdasta). Taulukosta 8 käy edelleen ilmi edellisiin fraktioihin pääasiallisesti vaikuttavien hemiselluloosa- ja selluloosamäärien keskimääräiset eroavaisuudet. Saraturve näyttää sisältävän vain noin puolet rahkaturpeen sisältämästä selluloosa- ja hemiselluloosamäärästä. Myös A-fraktio, eli

happoihin liukeneva orgaaninen ainemäärä, joka ei ole hemiselluloosaa, selluloosaa eikä valkuaisaineita, vaan pääasiallisesti humiinihappoja, on saraturpeissa huomattavasti pienempi ja suurin vähimmin maatuneissa turpeissa kummassakin turveryhmässä. Veteen liukenevia aineita sisältävät rahkaturpeet eniten ja tulokset ovat likimain yhtäpitäviä muiden tutkijoitten esittämien tulosten kanssa. Maatumisen alkuvaiheissa on vesiliukoisten aineitten määrä suurin. Huomattavim- 
Taulukko 8. Rahka- ja saraturpeitten analyysien keskiarvoja (6 kpl. S-t. näytettä, maatumisasteet $\mathrm{H}_{2}, \mathrm{H}_{5}, \mathrm{H}_{5}, \mathrm{H}_{6}, \mathrm{H}_{7} \mathrm{H}_{9}$ ja $6 \mathrm{kpl}$. C-t. näytettä, maatumisasteet $\mathrm{H}_{4}, \mathrm{H}_{5}, \mathrm{H}_{5}, \mathrm{H}_{6}, \mathrm{H}_{7}, \mathrm{H}_{8}$ ).

Table 8. Mean values of results of analyses of $C$-peat and $S$-peat (6 samples of $S$-peat degree of humification $\mathrm{H}_{2}, \mathrm{H}_{5}, \mathrm{H}_{5}, \mathrm{H}_{6}, \mathrm{H}_{7}, \mathrm{H}_{9}$ and 6 samples of $\mathrm{C}$-peat degree of humification $\mathrm{H}_{4}, \mathrm{H}_{5}, \mathrm{H}_{5}, \mathrm{H}_{6}, \mathrm{H}_{7}, \mathrm{H}_{8}$ ).

Prosenteissa kuiva-aineesta - In \% of dry material

Bitumifraktiota. - Bitumen

Vesiliukoista fraktiota. — Water soluble fraction $\ldots$

$2 \% \mathrm{HCl}$ liukoista fraktiota. - Soluble in 2 per cent $\mathrm{HCl} \ldots \ldots \ldots \ldots \ldots$

$80 \% \mathrm{H}_{2} \mathrm{SO}_{4}$ liukoista fraktiota. - Soluble in 80 per cent $\mathrm{H}_{2} \mathrm{SO}_{4} \ldots \ldots \ldots \ldots$

Hydrolysoitumatonta jäännöstä. - Unhydrolyzable residue ...........

Prosenteissa tuhkattomasta kuiva-aineesta: - In \% of ashfree dry material:

Org. vesiliukoisia aineita. - Org. watersoluble material ..............

Hemiselluloosaa. - Hemicelluloses

S-turve

C-turve

$S$-peat

C-peat

$8.26 \% \quad 11.0 \%$

3.87

2.39

39.54

26.96 i

16.71

10.74

31.62 , 48.91 ,

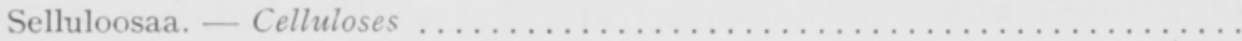

Org. hydrolysoitumatonta ainesta. - Org. unhydrolyzable material

Org. A-fraktiota.

- Org. A-fraction

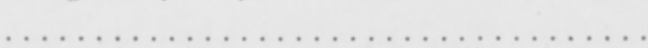

Vapaata raakaproteinia. -- Free crude protein

$\begin{array}{rr}8.38 \% & 11.38 \% \\ 3.77 & 2.21 \\ 25.39 \% & 13.00 \\ 14.62 \% & 7.17 \\ 31.64 & 49.89 \\ 12.89 & 7.21 \\ 3.31 & 9.14\end{array}$

min kirjallisuudessa esiintyvistä analyysituloksista poikkeavat oheisten analyysien saraturpeitten selluloosan ja hemiselluloosan määrät, jotka ovat suurempia.

Tässä yhteydessä ei ole mahdollisuutta tarkemmin puuttua Suomen turpeitten kemiallisen kokoomuksen vaihteluitten syihin, jotka on etsittävä paitsi turvetta muodostavasta kasvillisuudesta ennen kaikkea mikrobiologian alalta. Ylläesitetyllä tutkimuksella lieneekin arvonsa lähinnä mikrobiologian palveluksessa saavutettuja tuloksia sovellettaessa. Turveanalyysien tuloksia puolestaan voidaan soveltaa teknillistä turvetutkimusta palvelemaan. Sellainen sovellutus on esimerkiksi polttoturpeitten arvon selvittäminen, johon seuraavassa lähemmin kiinnitetään huomiota.

\section{Kemiallisen kokoomuksen vaikutus polttoarvoon.}

Tämän tutkimuksen turvebitumeja käsittelevässä osassa on jo viitattu eetteriin ja alkoholiin liukenevien komponenttien merkitykseen polttoturpeitten lämpöarvoissa. Kuten edelläolevista turveanalyysitaulukoista käy ilmi, muodostavat veteen liukenevat ja hapoilla hydrolysoituvat aineet pääosan eli n. $60 \%$ rahkaturpeittemme ja n. $40 \%$ saraturpeittemme kemiallisesta kokoomuksesta. Nämä aineet ovat pääasiallisesti hiilihydraatteja ja valkuaisaineita sekä niitten hajoamisja muuttumistuloksia sekä ligniinin hajoamisesta peräisin olevia aineita. Polttoturpeen rakennekomponenteista ne ovat hiiliköyhimpia ja omaavat alhaisimman lämpöarvon. Jotta saataisiin jonkinlainen kuva turvefraktioitten lämpöarvoista määritettiin eräitten turvenäytteitten bitumifraktion ja hydrolysoitumattoman jäännöksen sekä alkuperäisten turpeitten kalorimetriarvot ja turpeitten analyysitulokset tuntien laskettiin ylläesitetyn vesiliukoisen ja hapoilla hydrolysoituvan osan kalorimetriarvot. Kaikki kalorimetriarvot laskettiin tuhkattomalle aineelle, jotta saataisiin selvempi kuva juuri turpeen orgaanisen aineksen luonteesta. Tulok- 
set on esitetty taulukossa 9. Siinä on bitumifraktion kalorimetriarvot saatu määrittämällä yhden rahkaturpeen ja yhden saraturpeen eetteriin liukenevan ja vesiuutoksen jälkeen alkoholiin liukenevan bitumiaineksen kalorimetriarvot ja näitä arvoja käyttäen laskettu eri turpeitten totaalibitumifraktion kalorimetriarvot analyysitulosten perusteella. Tarkemmin ei siis ole otettu huomioon etteriin ja alkoholiin liukenevan aineksen kalorimetriarvojen todennäköisiä maatumisesta riippuvia muutoksia. Tuloksia tarkasteltaessa huomataan, että yllämainitun veteen liukenevan ja hapoilla hydrolysoituvan fraktion kalorimetriarvot ovat rahkaturpeilla alhaisemmat kuin saraturpeilla, mutta kummallakin turvelajilla korkeammat kuin esim. selluloosalla, jonka kal. arvo on $4181 \mathrm{kkal} / \mathrm{kg}$. Se, että k.o. analyysifraktion lämpöarvo on korkeampi kuin hilihydraattien, jotka ovat fraktiossa pääosana, johtuu hiilirikkaammista orgaanisista aineista ("huminihapoista») eli analyysin A-fraktion aineista sekä valkuaisaineista, joita saraturpeet sisältävät tunnetusti enemmän kuin rahkaturpeet. Vertailun vuoksi mainittakoon, että rahkaturpeen veteen liukenevan orgaanisen aineksen kalorimetriarvoksi saatiin kokeissa 4072 $\mathrm{kkal} / \mathrm{kg}$ ja kahden pohjois-Pohjanmaan suon laskuveden humaattisaostuman kalorimetriarvoiksi saatiin 4299 ja $4364 \mathrm{kkal} / \mathrm{kg}$ laskettuna tuhkattomalle aineelle.

Hydrolysoitumattoman jäännösfraktion kalorimetriarvoissa nähdään taulukossa 9 myös huomattava ero rahkaturpeitten ja saraturpeitten välillä. Viimemainittujen turpeitten jäännösfraktio osoittautuu kokoomukseltaan huomattavasti energiarikkaammaksi kuin rahkaturpeitten vastaava fraktio. Rahkaturpeissa näyttää fraktion kalorimetriarvo maatumisen alkuvaiheessa laskevan ja sitten jälleen nousevan. Vastaavaa havaintoa ei aineiston pienuuden vuoksi voitu tehdä saraturpeilla. Jäännöksen kalorimetriarvoja tarkasteltaessa on otettava huomioon mahdollisesti uutoksessa epätäydellisesti pois liuenneen bitumiaineksen vaikutus, joka tuntuu varsinkin vähän ligniiniä ja sen hydrolysoitumattomia muuttumistuloksia sisältävissä turpeissa.

Useat tutkijat $(7,12,17,26)$ ovat esittäneet ja korostaneet eri turvelajien eri suuria polttoarvoja ja maatumisen aiheuttamia muutoksia niissä. Tämän tutkimuksen yhteydessä on käynyt havainnolliseksi, mistä seikoista turpeitten kemiallisessa kokoomuksessa nämä erot pääasiallisesti johtuvat. On nähty, ettei ainoastaan eri suuret määrät samoihin orgaanisiin aineryhmiin kuuluvia rakennusosia turvetta muodostavissa kasvilajeissa ja vastaavissa turvelajeissa, vaan myös näiden aineryhmien kemiallinen kokoomus ja sen vaihtelut vaikuttavat lämpöarvoihin. Niihin biokemiallisiin ja mikrobiologisiin prosesseihin, jotka aiheuttavat kasvimateriaalin maatumista, vaikuttavat, kuten on mainittu, suuresti useat erilaiset esim. ilmastolliset ja geologiset seikat. Täten ei kasvinjätekokoonpanoltaan ja maatumiseltaan samanlaisten turpeitten läheskään aina tarvitse olla kemialliselta kokoonpanoltaan ja lämpöarvoltaan samanlaisia.

Kalorimetriarvojen suuruusluokan ja vaihtelujen osoitukseksi on taulukkoon 9 merkitty tutkittujen turvenäytteitten kokonaiskalorimetriarvot laskettuna tuhkattomalle kuiva-aineelle. Suuren tutkimusmateriaalin perusteella on SALmi (17) laskenut suomalaisten turpeitten keskimääräisiä polttoarvoja ja todennut muutoksia, joitten syitten selvittämiseen jatkuvat kemialliset tutkimukset ovat tarpeen. 
Taulukko 9. Turveanalyysifraktioiden sekä alkuperäisten turpeitten kalorimetriarvoja laskettuna $\mathrm{kkal} / \mathrm{kg}$ tuhkatonta ainetta.

Table 9. Gross calorific values of the original kinds of peats and of the different fractions, calculated on ashfree material.

\begin{tabular}{|c|c|c|c|c|c|}
\hline $\begin{array}{l}\text { N:o } \\
\text { No. }\end{array}$ & $\begin{array}{c}\text { Turvelaji ja } \\
\text { maatuneisuus } \\
\text { Kind of peat and } \\
\text { humification }\end{array}$ & $\begin{array}{l}\text { Bitumifraktion } \\
\text { kal.a. }{ }^{1)} \\
\begin{array}{l}\text { Gross cal. value of } \\
\text { bitumen fraction }\end{array}\end{array}$ & $\begin{array}{l}\text { Vesi- ja happoliukoi- } \\
\text { sen fraktion kal.a. }{ }^{2} \\
\text { Gross cal. value of } \\
\text { water soluble and acid } \\
\text { soluble fractions }\end{array}$ & $\begin{array}{c}\text { Hydrolysoitumat- } \\
\text { toman jäännöksen } \\
\text { kal.a. } \\
\text { Gross cal. value of } \\
\text { unhydrolyzable } \\
\text { residue } \\
\end{array}$ & $\begin{array}{c}\text { Kokonais kal.a. } \\
\text { Total gross } \\
\text { cal. value }\end{array}$ \\
\hline 1 & $\mathrm{~S}-\mathrm{t} \mathrm{H}_{2}$ & 8056 & 4249 & 5827 & 4653 \\
\hline 2 & $\mathrm{ErS}-\mathrm{t} \mathrm{H}_{2}$ & 8182 & 4255 & 5765 & 4698 \\
\hline 20 & $\mathrm{~S}-\mathrm{t} \mathrm{H}_{3}$ & 8202 & 4180 & 5734 & 4751 \\
\hline 3 & $\mathrm{~S}-\mathrm{t} \mathrm{H}_{5}$ & 8076 & 4222 & 5496 & 4905 \\
\hline 4 & $\mathrm{~S}-\mathrm{t} \mathrm{H}_{7}$ & 8261 & 4290 & 5529 & 4987 \\
\hline 5 & $\mathrm{~S}-\mathrm{t} \mathrm{H}_{5}$ & 8267 & 4223 & 5565 & 5060 \\
\hline 6 & $\mathrm{~S}-\mathrm{t} \mathrm{H}_{6}$ & 8292 & 4242 & 5739 & 5161 \\
\hline 7 & $\mathrm{~S}-\mathrm{t} \mathrm{H}_{9}$ & 8207 & 4495 & 6047 & 5607 \\
\hline 8 & C. rostrata & - & - & - & 5065 \\
\hline 9 & $\mathrm{C}-\mathrm{t} \mathrm{H}_{4}$ & - & 一 & - & 5515 \\
\hline 10 & $\mathrm{LC}-\mathrm{t} \mathrm{H}_{5}$ & 8317 & $469 \stackrel{4}{4}$ & 5959 & 5622 \\
\hline 11 & $\mathrm{LC}-\mathrm{t} \mathrm{H}_{6}$ & - & - & -- & 6025 \\
\hline 12 & $\mathrm{LC}-\mathrm{t} \mathrm{H}_{7}$ & 8656 & 4649 & 6354 & 6050 \\
\hline 13 & $\mathrm{C}-\mathrm{t} \mathrm{H}_{5}$ & 8408 & 4642 & 6277 & 5973 \\
\hline 14 & $\mathrm{C}-\mathrm{tH}_{8}$ & 8309 & 4807 & 6258 & 5981 \\
\hline 15 & Scorp. - $-t$ & - & - & 5628 & 4866 \\
\hline 16 & $\mathrm{AC}-\mathrm{t} \mathrm{H}_{3}$ & - & - & 5774 & 5246 \\
\hline 17 & $\mathrm{AC}-\mathrm{t} \mathrm{H}_{4}$ & - & 一 & 5416 & 5055 \\
\hline 18 & $\mathrm{AC}-\mathrm{t} \mathrm{H}_{6}$ & - & 一 & 5833 & 5462 \\
\hline
\end{tabular}

1) Laskettu seuraavien määritysten perusteella:

C-turpeen eetteriin liukenevan bitumin kal.a. $9311 \mathrm{kkal} / \mathrm{kg}$,

\begin{tabular}{|c|c|c|c|c|c|}
\hline ) & alkoholiin & ") & ") & ") & 7434 \\
\hline turpeen & eetteriin & $"$ & ) & $n$ & 9346 \\
\hline i) & alkoholiin & $\Rightarrow$ & ") & $"$ & 7365 \\
\hline
\end{tabular}

Calculated with the aid of the following values.

Cal. value of ether soluble bitumen fraction of S-peat $=93 I I \mathrm{kcal} / \mathrm{kg}$

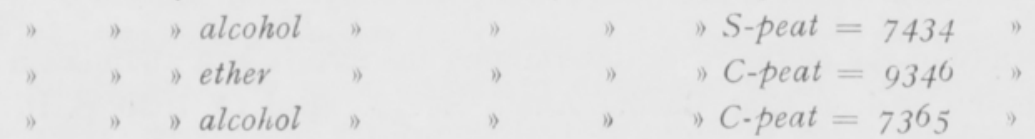

2) Arvot saatu laskemalla.

Values obtained by calculation. 
(1) Anttinen, O., 1917. Der Aschengehalt verschiedener Torfarten und Torfartgruppen. Finska mosskulturföreningens årsbok, 1917, XXXI, p. 108-113.

(2) Christiansson, B., 1947. Studium över tjärbildningen vid pyrolus av några olika svenska torvarter. IVA, 19-7, 6, Stockholm.

(3) Feustel, I., Byers, H., 1930. The physical and chemical characteristics of certain american peat profiles. U. S. Dept. of Agric., Techn. Bull., 214.

(4) Forsyth, W. G. C., 1946. The characterization of the humic complexes of soil organic matter. Journ. of Agric. Science, Vol. 37, Part. 2, p. 132.

(5) Fuchs, W., 1931. Die Chemie der Kohle. Berlin.

(6) Gaardner, T. \& Alvsaker, E., 1938. Humusen i udyrket Vestlandsjord. Vestlandets forst. forsokss., Meddelelse nr. 21. Bergen.

(7) Hausding, U., 1919. Torfgevinnung und Torfverwertung. Berlin.

(8) Kivinen, E., 1934. Über die organische Zusammensetzung der Torfarten und einiger Torfkonstituenten. Acta Agralia Fennica, 31, p. 165.

(9) — - 1935. Über Elektolytgehalt und Reaktion der Moorvässer. Agrogeol. julk., 38.

(10) —- 1938. Die Moor-Böden Finnlands. Agrogeol. julk., 47.

(11) Kotilainen, M. J., 1927. Soiden luontaisen kasvipeitteen ja pintaturpeen laadun, lähinnä sen reaktion välisestä suhteesta. Suomen suovilj. yhd. vuosik. 1927, 2, p. 114.

(12) Kusnetzowa, L. G. 1935. Der Heitzwert der verschiedenen Torfarten und der Torflager. Ref.: Jahrb. d. Moork. 1935: 156.

(13) Mrnssen, H., 1913. Beiträge zur Kenntnis typischer Torfarten. Landw. Jahrb., Bd. 44, p. 269.

(14) —- 1927. Weitere Beiträge zur Kenntnis typischer Torfarten. Landw. Jahrb., Bd. 65, Erg. Bd. 1, p. 124.

(15) Oden, S. \& Lindberg, S., 1926. Einige Torfanalysen im Lichte neuzeitlicher Theorien der Kohlebildung. Brennstoff-Chemie, 7 .

(16) von Post, L. \& Granlund, E., 1926. Södra Sveriges torvtillgångar. Sveriges Geol. Unders., ser. C., 335 .

(17) Salmi, M., 1947. Turpeiden tuhkapitoisuuksista ja lämpöarvoista. Tekn. aikak.lehti, 4, p. 151.

(18) Schneider, W. \& Schellenberg, A., 1922. Über den Bitumengehalt des Torfes. Ref.: Chem. Zbltt., IV, p. 1043.

(19) Souci, S. W., 1938. Die Chemie des Moores. Stuttgart.

(20) Stadnikoff, G., 1930. Neuere Torfchemie. Leipzig.

(21) Thiessen R. \& Johnsson, R., 1929. An analysis of a peat profile. Journ. of Ind. a. Eng. Chem., Anal. Ed., 1, p. 216.

(22) Titow N. G., \& Fedossejewa, S. F., 1939. Die Anwendbarkeit von Aethylalkohol-Benzol als Lösungsmittel zur Bitumenekstraktion. Ref.: Chem. Zbltt., 1939, Bd I., p. 1700.

(23) Waksman, S. \& Stewens, K., 1928. Chemical composition of various peat profiles. Soil Science 26, p. $239-251$.

(24) - - 1930. A critical study of the methods for determining the nature and abundance of soil organic matter. Journ. Ind. a. Eng. Chem., Anal. Ed., 2., april 15, 1930, p. 167.

(25) Waksman, S., 1938. Humus. Baltimore.

(26) Zailer, V. \& Wilk, L., 1911. Der Einfluss des Vertorfungsprozesses auf die Zusammensetzung von Carextorf. Zeitschrift für Moorkultur u. Torfverwertung, p. 193. 
S U M M A R Y.

\section{ON THE CHEMICAL COMPOSITION OF SOME VARIETIES OF FINNISH PEAT AND ITS INFLUENCE ON THEIR CALORIFIC VALUE.}

U. Soveri.

Finnish Geological Survey, Helsinki.

The aim of this work is to give the reader a general picture of the main constituents of some varieties of peat found in Finland, and the significance of these constituents in fuel peat. Attention has primarily been focussed on the thermodynamically important constituents of peat, i.e. bitumen, water soluble organic substances, proteins, substances hydrolyzable with acid (cellulose, hemicelluloses), substances unhydrolyzable with acid (lignin and the products of the decomposition of lignin) and ash. The method of analysis chiefly used was that of WAKsman and Stevens, which was, however, somewhat abbreviated.

The following varieties of peat were used: 8 samples of pure Sphagnum peat (S-peat), 7 samples of Carex peat (C-peat) of which three contained some wood waste (LC-peat) and one some unchanged Carex rostrata, 4 samples of Amblystegium Carex peat (AC-peat) and a profile consisting of Sphagnum peat containing some Eriophorum peat (Er S-peat). The samples were gathered in Northern Finland.

Ash: After discussion of the factors influencing the ash cuntent of peat and the composition of the ash, the results of the peat analyses carried out are considered. The ash of the acid soluble fraction contains mainly sesqui-oxides while the ash of the insoluble residue chiefly consists of $\mathrm{SiO}_{2}$ and silicates (secondary ash) (Table 2). Table 3 shows that: 1 ) The lightly humified surface peat $\left(\mathrm{H}_{1}-\mathrm{H}_{2}\right)$ generally contains considerably more water soluble ash and less acid soluble ash than the nore humified peat; 2) The acid soluble ash constituents seem to increase with the dept (decreasing acidity and precipitation of metal hydroxides); 3) Analyses of AC-peat show more acid soluble and less insoluble ash than Sand $\mathrm{C}$-peat (this agrees with the higher $\mathrm{pH}$-value of AC-peat).

Bitumen. The nature of bitumen, the methods of estimating the bitumen content of peat, and of previous investigations are discussed. The bitumen content of 30 samples of Er S-peat was determined by extraction with a benzene-alcohol mixture $(1: 1)$. The results are set out in Fig. 1 : Table 4 shows the results of the bitumen determinations according to Waksman's and Stevens' method. The following conclusions can be drawn: 1) AC-peat contains considerably less bitumen than S-peat and C-peat, and C-peat contains more bitumen than S-peat; 2) The results confirm the old theory that the bitumen content increases more markedly with the degree of humification in S-peat than in C-peat; 3) AC-peat has the smallest ether fraction (30.9\%) expressed in percentage of the total bitumen content, S-peat a somewhat higher $(\mathbf{4 0 . 5} \%)$, and C-peat the highest percentage $(50.8 \%)$. These results agree with those obtained by other scientists from analysis of Scandinavian material, but not with results obtained by Americau scientists with European and American material (see table 5).

Other organic constituents of peat. Fig. 1 shows the trend of change in the chemical composition which occurs in the humification of pure S-peat and S-peat containing some Eriophorum peat. Tables 6 and 7 show that the changes in the C-peat and S-peat follow the same general trend. The most obvious and thermodynamically most important difference in the chemical composition of these two kinds of peat is the considerably greater content of unhydrolyzable substance in the C-peat. Table 8 shows the difference in the composition of C-peat and S-peat. According to this, S-peat would appear to contain about twice as much cellulose and heri-cellulose as C-peat. S-peat also contains a greater proportion than C-peat of the A-fraction, which is that part of the acid soluble fraction that is not cellulose, hemicellulose or protein but consists mairly of humic acids. In both kinds of peat the least humified samples contained the largest proportion of A-fraction. The expression "Free crude protein" in table 7 means the protein quantity which is equivalent to the water and acid soluble quantity of nitrogen. The cellulose and hemicellulose content of C-peat have been found to be somewhat larger than those mentioned in the literature. The variations in the quantities of water soluble substances in all the samples of peat investigated correspond on the whole with the results published by other scientists. 
The influence of the chemical composition of peat on its calorific value. Table 9 shows the gross calorific values of the various fractions. The values have been obtained by determining the total gross calorific value, the gross calorific value of the residual fraction, and the gross calorific values of two ether and alcohol soluble fractions. These values have then been used in calculating the gross calorific value of the water and acid soluble fractions and of the bitumen fraction. The probable changes in the calorific values of both the ether and alcohol soluble substances, due to humification, have thus not been accurately taken into consideration. That C-peat has a higher calorific value than S-peat in spite of its higher ash content, is probably due to the following facts:

1) The bitumen content of C-peat is higher

2) The bitumen of C-peat contains more ether soluble substances

3) C-peat contains more proteins, which have a higher calorific value than hydrocarbons

4) C-peat contains more carbonaceous substances (lignin etc.) that are unhydrolyzable with acids.

5) The substances in C-peat which are unhydrolyzable with acids have higher calorific values than those of S-peat.

Thus the calorific value of peat does not depend only on the quantities of the various fractions in peat forming plants and the corresponding varieties of peat, but also on the variations in the chemical composition of these fractions. 